Int. J. Dev. Biol. 51: 483-493 (2007)

doi: $10.1387 / \mathrm{ijdb} .072343 \mathrm{ga}$

\title{
Establishment of a proneural field in the inner ear
}

\author{
GINA ABELLÓ and BERTA ALSINA* \\ Developmental Biology, Dept. of Experimental Sciences and Health, Pompeu Fabra University, Barcelona Biomedical Research Park, \\ Barcelona, Spain
}

\begin{abstract}
Hair-cells, supporting cells and sensory neurons are the main specialized cell-types responsible for mechanotransduction in the inner ear. They derive from precursors expressing proneural genes and recent data has underlined the importance of SoxB1 genes as upstream activators of proneural genes during cranial placode development. Here we review the steps of establishing a proneural field and propose several models for how early otic regionalization into a proneural territory is achieved.
\end{abstract}

KEY WORDS: bHLH, proneural gene, notch signaling, FGF signaling, SoxB1, neural induction

\section{Introduction}

Sensory organs provide key and species-specific information that allows animals to effectively forage, find mates and avoid predators. The inner ear is one of the main sensory organs of the head and responsible for the perception of sound and balance. In adults, the organ is arranged in a highly complex three-dimensional structure, named the membranous labyrinth, composed of ducts, recesses and six to eight sensory epithelia. The latter are composed of hair-cells - the mechanotransducers - and supporting cells arranged in a cellular mosaic. Mechanosensory information is then transmitted to the brainstem by afferent bipolar sensory neurons. Albeit the structural complexity of the adult inner ear, it derives from a simple anlage, the otic placode (Torres and Giraldez, 1998, Baker and Bronner-Fraser, 2001, Fritzsch and Beisel, 2001, Riley and Phillips, 2003). Cranial placodes are specialized areas of ectoderm outside the neural plate that contribute to all the cranial paired sensory organs and most of the sensory neurons from the peripheral nervous system of the head. The current view is that placodes share a common developmental origin, the preplacodal region (PPR), a horseshoe band encircling the neural plate from which individual placodes emerge (Jacobson, 1963, Torres and Giraldez, 1998, Streit, 2004, Schlosser, 2006). Except the adenohypophyseal and the lens placode, the rest of placodes (olfactory, profundal and trigeminal, otic, lateral line, epibranchial) are neurogenic, this means that they give rise to sensory neurons among other specialized cell-types (Adam et al., 1998, Ma et al., 2000, Schlosser and Northcutt, 2000, Andermann et al., 2002, Begbie et al., 2002).

During inner ear development, sensory neurons and hair-cells derive from otic precursors in which proneural genes are acti- vated. Despite the knowledge of proneural function and a general view of placodes as lateral neurogenic domains, little is known about how and when proneural competence is acquired in the otic placode. The aim of this review is to summarize the data concerning the mechanisms of proneural activation in the inner ear. Which proneural genes are functional during otic development in the different species? When and where are they activated? Which is the origin of proneural otic competence? The regulation of proneural function is tightly linked to Notch signaling activity. The second part of the review intends to highlight the function of Notch pathway in proneurosensory development.

\section{Activation of proneural genes in the inner ear}

After otic placode formation, the otic tissue invaginates and initiates its autonomous program of development. The most obvious change, apart from its continuous modulation of shape, is its progressive generation of specialized cells in precise locations. Once the placode invaginates, some epithelial cells identified as neuroblasts loose connectivity and delaminate into the mesenchymal space where they remain as a group forming the cochleo-vestibular ganglion (D'Amico-Martel, 1982, Hemond and Morest, 1991, Adam et al., 1998). There neuroblasts suffer a series of transit-amplifying rounds of division (Alsina et al., 2003, Camarero et al., 2003), to then enter into differentiation, extend their axons and innervate the epithelial regions near where they have been generated (Fritzsch et al., 2002). In the past decade,

Abbreviations used in this paper: bHLH, basic helix-loop-helix; FGF, fibroblast growth factor; Ngn, neurogenin; PPR, preplacodal region; SOP, sense organ precursor;

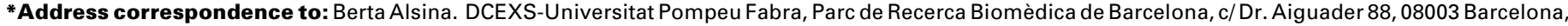
Spain. Tel: +34-93-316-0837. Fax: +34-93-316-0901. e-mail: berta.alsina@upf.edu. Web: http://www.upf.edu/cexs/recerca/biodes/index.htm
} 
many genes implicated in the process of neurosensory development have been identified both in invertebrates and vertebrates (Ghysen and Richelle, 1979, Torres and Giraldez, 1998, Baker and Bronner-Fraser, 2001). Now it is clear that the early steps of cell fate specification in the different sense organs are controlled by proneural genes, which were first identified in Drosophila mutants lacking the ability to develop external sense organs and bristles (Ghysen and Richelle, 1979). Proneural genes encode for transcription factors of the basic Helix-Loop-Helix (bHLH) class that bind to a common DNA sequence called the E-box sequence (Bertrand et al., 2002). In Drosophila, two major proneural gene families control neuronal development of the PNS, the achaetescute (asc) and the atonal(ato) gene family (Simpson, 1990). Asc genes in Drosophila specify external sense organs, while ato gene specifies the photoreceptors and chordotonal organs, among them the specialized Johnston's organ (Ghysen and DamblyChaudiere, 1989, Treisman, 2004). The latter, located in the fly antenna, appears to be the homologous hearing organ in Drosophila given its capacity of sound evoked potentials (reviewed in Caldwell and Eberl, 2002, Boekhoff-Falk, 2005; Eberl and BoekhoffFalk in this issue). In vertebrates, in addition to the achaete-scute homologues (ash) and the atonal homologues (atoh), other new related proneural families are encoded in the genome: the $\mathrm{E}$ proteins, Olig, NeuroD, Neurogenin and $\mathrm{Nscl}$ protein families (Bertrand et al., 2002), with some of them having been recruited for the peripheral sensory developmental program in craniates. It has been postulated that the appearance of new proneural genes in vertebrates allowed the ancestral functions of mechanotransduction and electrical propagation performed by a single cell to be segregated and performed by two different cells: the hair-cell specified by atoh and, the neuron, specified by Neurogenin (Neurog, also-named Ngn)(see Fritzsch and Beisel, 2001).

In Drosophila chordotonal organs, as a result of the activation of the Notch pathway, the sense organ precursor (SOP) is singled out from a group of equivalent cells expressing the ato proneural gene. After the selection of the SOP, proliferation initiates giving rise to the main cell types. Contrary to external bristles, in some chordotonal organs secondary precursors are recruited by external signals, such as EGFR signaling (zur Lage et al., 2004) (Figure 1). In amniote vertebrates, a proneural field expressing Neurog 1 is distinguished in an anterior subdomain of the otic placode. In this domain, scattered cells with increased levels of Neurog 1 and Delta1 appear in the otic cup in mouse and chick (Adam et al., 1998, Ma et al., 2000, Alsina et al., 2004). Similar to the chordotonal organs, several signaling molecules (in this case from the FGF family: FGF3, FGF8, FGF10) are expressed in the proneural field in zebrafish, chick and mice, their function probably also related to the recruitment of cells into the neurosensory lineage (Leger and Brand, 2002, Pirvola et al., 2002, Alsina et al., 2004). Following Neurog1expression, other genes of the proneural bHLH family (i.e. NeuroDand NeuroM) switch on, the expression detected in epithelial and delaminated neuroblasts (Figure 1). Functional analysis of Neurog 1 and NeuroDsuggests that they are necessary and sufficient for neurogenesis. Overexpression of Neurog1drives formation of ectopic neurons (Perron et al., 1999, Kim et al., 2001), while targeted inactivation of Neurog 1 results in loss of proximal cranial sensory ganglia (Ma et al., 2000). Disruption of NeuroD function also results in a severe loss of sensory neurons associated with the inner ear (Kim et al., 2001). The sequence of activation of Neurog1, followed by NeuroD/NeuroM expression plus the phenotypes observed supports the notion that Neurog genes have conserved the neuronal determination functions of the atonal Drosophila counterparts, whereas the NeuroD/NeuroMbHLH transcription factors exhibit neuronal differentiation and survival functions.

Hair-cell specification lags neuronal cell specification by approximately two days in amniotes. Few scattered cells expressing Atoh1 are detected in the prosensory patches in chick E3.5 otic vesicles (Pujades et al., 2006) and the sensory epithelia of E11E12 mice embryos (Shailam et al., 1999; Matei et al., 2005). By contrast, in zebrafish, sensory and neuronal precursors are specified almost about the same time (Andermann et al., 2002). Low expression of atoh1bin zebrafish precedes the appearance of individual atoh1a-positive hair-cells in a broad sensory field of equivalent cells. The initial development of this domain is regulated by Notch signaling like in Drosophila, suggesting a classical proneural role of atoh1b in zebrafish (Millimaki et al., 2007). In mammals, this role is less clear due to the appearance of Atoh1 mainly in post-mitotic cells and restricted to the cells that will differentiate into hair-cells (Chen et al., 2002), although in mice expression has been detected before the appearance of defined sensory patches by RT-PCR (Matei et al., 2005). In amniotes, neuronal and hair-cell determination events are segregated in time, with gross morphogenetic changes during this period. Thus, it is yet not resolved if Neurog1 and Atoh1 proneural activation occurs in a common proneurosensory domain or from segregated or partially overlapping neural (neuronal) and sensory domains. Lineage studies have determined that the macula utriculae contains progenitors with shared neuro-sensory lineage in chick and Neurog 1 mice mutants display also loss of hair-cells, indicating that at least in some areas exist common progenitors for both cell lineages (Satoh and Fekete, 2005). However, as Neurog 1 and Atoh 1 genes are expressed broadly at nearly undetectable levels and only enhanced at determined cells, analysis of the distribution of Sox proteins may constitute better readouts of proneurosensory committed territory/ies. In neural development, Sox genes are expressed before proneural genes (see below) and Sox2mutants present severe defects in sensory organ development, lacking also Atoh1 expression (Kiernan et al., 2005). Sox3 and Sox2 proteins are both present in the anterior ventral otic cup but later on, exclusively Sox2 map in the sensory patches (Neves et al., 2007).

\section{Inducing neural competence in the otic placode}

During early development of the embryo, the Fibroblast Growth Factor (FGF), Wingless/int-2 (WNT) and Bone Morphogenetic Protein (BMP) signaling pathways repeatedly converge to induce ectodermal tissue to a neural fate as shown for neural plate and neural crest inductions. The current view on this process is that FGF and/or WNT signals are required to inhibit BMP signaling, the earliest pathway described to potentiate epidermal fate over neural fate (Stern, 2005). Two key recent reports begin to elucidate how FGF and BMP signaling pathways converge intracellularly during early embryogenesis. The first, reports a direct phosphorylation of MAPK on smad1 to inhibit BMP signaling (Pera et al., 2003) and the second, the finding that Sip1, a 
Smad-interacting protein 1, is regulated by Churchill, a gene isolated after neural induction mediated by FGF (Sheng et al., 2003). The relationship of FGF signaling and proneural activation comes from studies in the emerging caudal CNS, where Cash4 is activated by FGF (Henrique et al., 1997). However, in most cases switch on of proneural genes is delayed to neural induction and their activation is mediated by early induced pan-neural genes (Sox, ENRI, Zic) that then regulate proneural activity.

Sox proteins form a family of HMG-box transcription factors related to SRY, the mammalian testis determining factor. On the basis of sequence similarity, both in the DNA-binding domain and in other, group-specific conserved motifs, Sox proteins have been divided into at least seven subgroups (A-G). Throughout evolution, the expression of the SoxB1 genes (Sox1, Sox2 and Sox3), directly correlates first, with ectodermal cells that are competent to acquire a neural fate and second, with the commitment of cells to a neural fate (Rex et al., 1997, Pevny and Placzek, 2005). The Drosophila SoxNeuro, a putative ortholog of the vertebrate Sox1-3 proteins, is one of the earliest transcription factors to be expressed pan-neuroectodermally (Cremazy et al., 2000) and it acts upstream and in parallel with the achaete-scute genes. Interestingly in Drosophila, SoxNeuro is only involved in CNS but not in PNS development, being suggested that recruitment of Sox proteins into placode development is a novelty of craniates to expand the ectodermal anlage rapidly (Fritzsch et al., 2006b). Direct evidence for the involvement of SoxB1genes in neural commitment comes from in vitro stem cell studies, where it was shown that the Sox1 gene can induce neural fate in competent ectodermal cells (Pevny et al., 1998). Consistent with SOXB1 factors marking ectodermal cells with neural potential their expression is modified by neural inducing signals (Streit et al., 2000). Moreover, strong evidence of the link between neural inducing signals and Sox activation is derived from the identification of FGF and Wnt response binding domains in the same enhancer region of the Sox2 locus (Takemoto et al., 2006).

The induction of the preplacodal region from which sensory cranial placodes emerge is mediated by the same signaling pathways. In this case, the activation of the FGF pathway, together with WNT and BMP antagonists specifies the preplacodal field (Ahrens and Schlosser, 2005, Litsiou et al., 2005). After the formation of the preplacodal region, a second wave of induction in particular locations, promotes a series of subdomains. Although, at the end in amniotes six placodes develop (adenohypophyseal, lens, olfactory, trigeminal, epibranchial and otic), an intermediate step of placodal development is identified by the appearance of three broad domains of Pax gene family expression: an anterior domain Pax6 positive, a second domain Pax3-postive next to the midbrainhindbrain boundary, plus a caudal region expressing Pax2 (Bhattacharyya and Bronner-Fraser, 2004). In the Pax6 domain, precursors of the adenohypophyseal, lens and olfactory

A

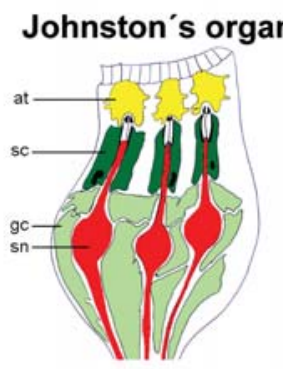

i) atonal field

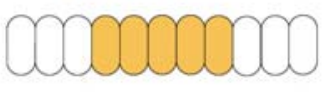

ii) selection SOP precursor ato/D/ cell

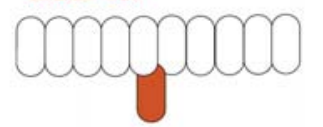

Drosophila

B

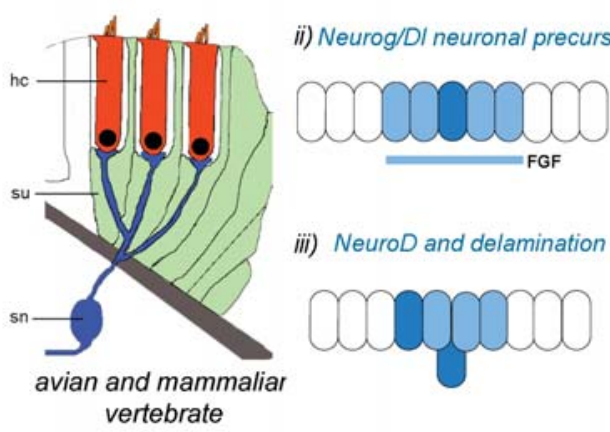

iii) EGF recruitment

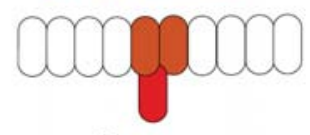

iv)

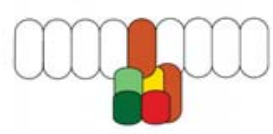

Inner ear

iv) $\mathrm{n}$
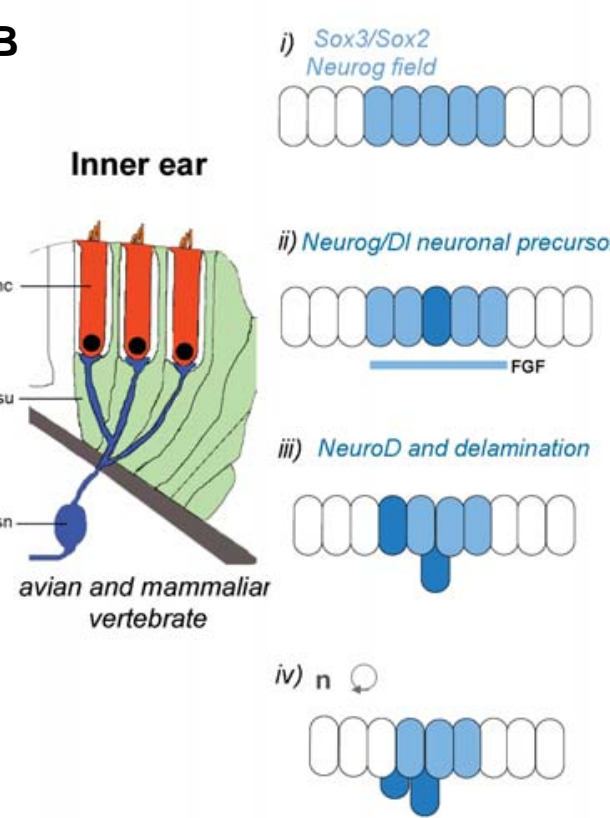

v) $S$ atoh field?

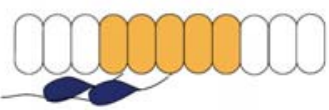

vi) atoh precursor

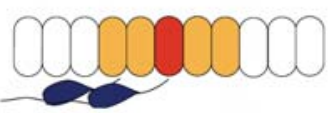

vii) $\mathrm{n} \bigcirc$

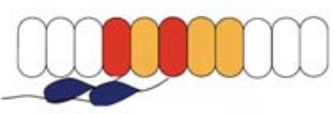

viii) atoh/DI hair-cell

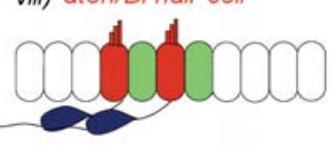

Fig. 1. Steps of proneural gene activation in vertebrate and invertebrate sensory organs. (A) Schematic drawing of three chordotonal sensilla of Drosophila (modified from Yager, 1999) and sequential steps of insect sensory development. i) a neurosensory field is specified by atonal proneural gene, ii) a SOP is singled out by the $\mathrm{N}-\mathrm{D}$ I pathway, iii) EGF recruits secondary precursors and iv) sensory neuron and accessory cells are generated. at, attachment cell; sc, scolopale cell; gl, glial cell; sn, sensory neuron. (B) Sensory patch of the vertebrate inner ear (Fettiplace and Hackney, 2006) and outline of major steps of sensory development. i) A proneural field is specified by Neurogenin, ii) neuronal precursors are singled out by the N-D/ pathway, iii) NeuroD is switched on, v) neuroblasts delaminate and differentiate, vil atoh starts to be expressed in a prosensory field, vii) sensory precursors are singled out, viii) hair-cells and supporting cells are determined by the activity of Notch pathway. sn, sensory neuron; hc, hair cell; su, supporting cell.

are initially intermingled and then sort out to different regions (Bhattacharyya et al., 2004). The Pax3 and the Pax2 domain contain precursors for the trigeminal placode and the epibranchial/otic precursors respectively (Baker and BronnerFraser, 2000, Schlosser and Ahrens, 2004). At the end, individual placodes will be identified by a combination of Pax, Six/ Eya, Foxiand Soxtranscription factors. Six proteins are usually expressed from the initial preplacodal field to the late individual 
placodes. In some vertebrate species, the expression of Sox2 and Sox 3 in the ectoderm arises in two waves; initially they are expressed at low levels in the preplacodal region, then expression is transiently shut off from the presumptive placode domains and finally it resumes when individual placodes are specified and express Pax genes (Abu-Elmagd et al., 2001, Schlosser and Ahrens, 2004, Sun et al., 2007). For example in the lens field, Sox2 expression is enhanced once the lens contacts the optic vesicle (Kamachi et al., 1998). All cranial placodes, neurogenic and non-neurogenic, except the trigeminal placode, express SoxB1 transcription factors. In Xenopus Neurog 1 expression is initiated in the entire preplacodal ectoderm but subsequently is shut off in lens, suggesting that all placodes in fact have an initial neural bias (Schlosser and Ahrens, 2004).

In chick, the otic proneural territory expressing Neurog1 emerges as a triangle in the anterior half of the flat otic placode. Initially the proneural domain is the anterior-medial aspect of the otic placode to end up, after invagination, in an anteriormedial and ventral position of the otic vesicle (Alsina et al., 2004). Before the otic placode is morphologically visible, Sox3 is expressed in a broad band that encompasses the otic and epibranchial territory to get restricted to the proneural region of the otic placode (Sun et al., 2007; G.A and B.A, unpublished observations). Two main questions arise when analyzing Sox function during otic development. First, does the process of placodal induction, by default, involve proneural induction or, alternatively, do successive induction events lead first to placodal and subsequently to neural fate? Secondly, is neural competence only acquired in a subdomain of the otic fated cells or is repression of neural fate required in the non-neural competent region? We propose several models on how the proneural domain may be established (Figure 2) by using the Sox3 expression as the earliest marker of neural induction and Pax2 as markers of placode induction.

\section{Model A: Single induction and repression of neural fate}

This model suggests that the competence of neural fate is conditioned by the acquisition of a placodal identity (Figure 2A). The fact that FGF signaling is required both for otic/epibranchial induction, as well as for Sox1-3 gene expression in the otic/ epibranchial field in zebrafish (Sun et al., 2007) suggest that both events could, in fact, be part of the same process. In addition, Sox2 is able to regulate the expression of a typical placodal marker such as PaxG in lens and nasal placodes (Donner et al., 2007) and in Medakaectopic expression of Sox3 induces ectopic otic and lens placodes expressing Pax2 and Pax6 respectively (Koster et al., 2000). In the posterior preplacodal region Six 1 and Sox 3 expression correlate in a higher degree but not in the anterior preplacodal field of Xenopus (Schlosser and Ahrens, 2004). Again at the otic-epibranchial field, Pax2 and Sox3 are also co-expressed in zebrafish and chick, although in the latter the appearance of Sox3expression is delayed to Pax2 (Groves and Bronner-Fraser, 2000, AbuElmagd et al., 2001, Sun et al., 2007). Altogether, Sox2-3 expression and placodal marker expression such as Pax and Six are strongly paralleled. However, albeit some data may suggest that placode and neural fate could be linked, there is little functional evidence supporting this model. In this model, as in model $\mathrm{c}$, proneural fate is inhibited in the posterior otic territory after broad placodal induction (see below).

\section{Model B: Successive inductions and restricted neural in- duction}

This model postulates that placodal and neural induction are successive events (Figure 2B). Graft experiments at different axial levels performed by Noden and Van De Water, (1986) revealed that presumptive otic placode ectoderm could ectopically generate otic vesicles without the ability to form neurons. Again, Groves and Bronner-Fraser (2000) observed that quail anterior epiblast grafted in the presumptive otic region of host of 3-10 somites could start to express Pax2 and Sox3, while grafts performed at 11-21 somites, only expressed Sox3 but not Pax2, suggesting that Pax2-inducing signals are lost before Sox3inducing signals. Thus, depending on the lenght of exposure of signals the appearance of some molecular markers, such as Pax2 and Sox3, can be dissociated. Inhibition of FGF signaling in zebrafish indicates that induction of Sox3and Pax2requires FGF signaling at the otic-epibranchial region but not in an interdependent manner (Groves and Bronner-Fraser, 2000, Nikaido et al., 2007, Sun et al., 2007). Consistent with a view of a multi-step inductive process for full otic development, it is well established that induction of the otic placode demands first the induction of the preplacodal ectoderm, biasing the ectoderm for receiving a second wave of induction (Litsiou et al., 2005, Martin and Groves, 2006).

This model also hypothesizes for a restricted source of neural inducers in the anterior otic field. So far, requirement of FGF signaling has been mainly associated with otic induction, but as reported recently this process probably also involves epibranchial induction (Hans et al., 2007, Nikaido et al., 2007, Sun et al., 2007, Nechiporuk et al., 2007). Several FGFs are expressed in surrounding tissues at the time of otic and Sox3induction. Several laboratories have addressed the issue concerning the identification of the signals involved in otic induction. The current view is that FGF8 from the endoderm, FGF19/ FGF10 from the mesoderm and FGF3/FGF8/FGF10 from the hindbrain are involved sequentially and sometimes synergistically to induce the already biased ectoderm to develop the inner ear (for review see Groves, 2005; Groves, Schimmang in this issue). FGF molecules (22 in mammals) regulate a wide variety of functions such as cell fate, patterning, proliferation, differentiation, survival and morphogenesis. During inner ear development, FGF also regulate some of these later events, such as patterning and growth (Wright and Mansour, 2003). Single mutants for FGF3 or hindbrain patterning genes like kreisler, in which FGF3 levels in the posterior hindbrain are reduced/lost show otic patterning defects such as expansion of the cochlea and absence of endolymphatic duct (Mansour et al., 1993, McKay et al., 1996, Choo et al., 2006). In zebrafish, the valentino mutant (zebrafish orthologue of kreis/er) displays an expansion of the anterior otic domain and overproduction of haircells, probably due to the posterior expansion of FGF3 expression within the hindbrain (Kwak et al., 2002). Likewise, the vHNF1 mutant embryos, also displaying an anteriorization of the hindbrain, again shows a caudal expansion of neurogenic and sensory domains at the expense of posterior and dorsal markers (Lecaudey et al., 2007). Some of these effects can be also mediated by WNT molecules that act synergistically with FGFs to 
promote neural character. However, one should bear in mind that some of the inner ear phenotypes affecting expansion and/or reduction of neuronal or sensory territories have been analyzed at otic vesicle stage when major morphogenesis and cell growth also occurs, with some of these pathways participating also in the mentioned processes. In summary, many FGFs and WNT molecules are locally expressed around the presumptive otic field in different time periods, therefore it is reasonable to believe that $i$ ) type, ii) time and, iii) space activation of these signals may differentially regulate placode and otic neural induction. In chick, FGF2 was able to induce a vast array but not all early otic markers (i.e. Pax2, EphA4, Nkx5.1, SOHo1, but not BMP7, D/x5), while FGF8 had some but little inducing properties (Adamska et al., 2001, Martin and Groves, 2006). Altogether, in this moment, a detail study on the roles of different FGFs on activating specific early otic genes is needed for drawing the full picture.

\section{Model C: Successive inductions and repression of neural fate}

This model predicts on successive inductions, as in model b, but unrestricted neural inducing signals activate Sox genes in a broad otic/epibranchial field. Broad proneural competence is subsequently restricted to the anterior otic region by an inhibitory signal from the posterior region (Figure $2 \mathrm{C}$ ). To date, Tbx1, a transcription factor belonging to the T-box gene family, is the only factor that clearly has been demonstrated to inhibit neurogenesis function in the posterior inner ear (Vitelli et al., 2003, Raft et al., 2004, Xu et al., 2007). In mice, Tbx 1 is expressed in pharyngeal arches, head mesenchyme, the secondary heart field, the posterior otocyst and sclerotome (Chapman et al., 1996). Homozygous mutation of $T b \times 1$ gene in mouse causes birth defects derived from developmental abnormalities of the embryonic pharyngeal system. The otocyst also presents major defects, being small and sensory organs do not form (Vitelli et al., 2003). Interestingly, Tbx1 is expressed in the nonneural otic vesicle region, complementary to NeuroD positive domain. Loss of $T b \times 1$ gene causes the expansion and duplication of the neural region while neural determination is suppressed in Tbx 1 gain-of-function otocysts, suggesting that its function is required to inhibit neuronal fate (Raft et al., 2004). This has been further demonstrated by fate mapping; Tbx 1 positive cells identify a population of cells that give rise to most of the otocyst, excluding the neurogenic and endolymphatic duct regions (Xu etal., 2007). In chick, two complementary domains are detected at early otic cup stage: a proneural region expressing LFng, FGF10/ FGF3, Delta1 and Hes5 and a non-neural region expressing $L m \times 1$, Irx 1 , Tbx 1 , Hairy 1 and Serrate1(Alsina etal., 2004, Abelló et al., 2007).

Hairy another bHLH gene is in Drosophila expressed in broad areas in which proneural function is repressed (Orenic et al., 1993). The legs of the Drosophila melanogasteradult are covered with bristles in a periodic pattern.
It has been shown that hairycontrols the pattern of sensory organ formation by repressing achaete-scute(Orenic etal., 1993). In the zebrafish midbrain-hindbrain boundary, mouse olfactory placode and the inter-proneural stripes of Xenopus, Hairy and Enhancer of Split homologues (Hes/Her) repress neural fate (Cau et al., 2000, Geling et al., 2003, Bae et al., 2005). In chick otic cups, Hairy 1 (Hes 1in mammals) is expressed restricted in the nonneural domain, disclosing a putative role in repressing proneural fate in the posterior region (Abelló et al., 2007). This links us to the following section in which the role of Notch pathway in defining sensory and neural domains are discussed.

In all three models, proneural function is probably enhanced by local otic FGF signals. For example, FGF3, FGF10 and FGF8 expressions are distinguished in the proneural territory in various species with reported neurogenic functions for some of them.

\section{Notch signaling during early otic development}

\section{Principles of the Notch signaling pathway}

Notch signaling pathway is involved in almost every developmental decision and process and together with the FGF, WNT, TGF $\beta$ and $\mathrm{HH}$ family proteins constitute one of the five main pathways required for metazoan development. The first identification of the Notch receptor arose in laboratories working on the fruit fly, Drosophila melanogaster, when a series of mutants that generated a Notched (indented) wing phenotype plus an overproduction of neural cell-types at the expense of nonneural cells were isolated. The core signaling pathway consists of the Notch receptor, with a large extracellular domain with 36 tandem epidermal growth factor (EGF)-like repeats and three cysteine-rich Notch/ LIN-12 repeats. Six tandem ankyrin repeats, a glutamine-rich domain (opa) and a PEST sequence are found within the intrac-

\section{A) Single induction \& repression of neural fate}

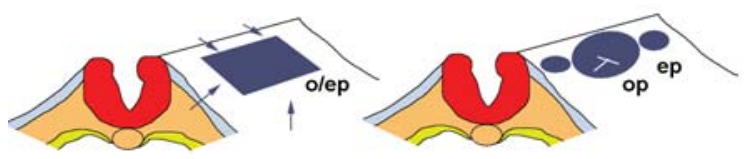

B) Successive inductions \& restricted neural induction

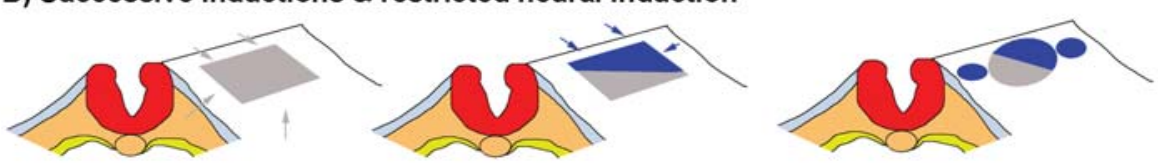

C) Successive inductions \& repression of neural fate

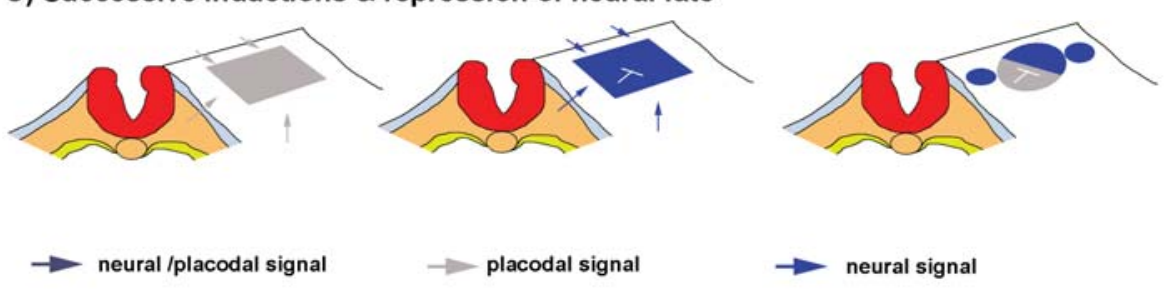

Fig. 2. Proposed models for neural induction in the otic/epibranchial field. Dorsal views of the cranial ectoderm at the level of the hindbrain. o/ep, otic-epibranchial placode; ep, epibranchial placode; op, otic placode. 
ellular domain (reviewed in Artavanis-Tsakonas et al., 1999). The ligands that bind to the Notch receptor are two single-pass proteins, Delta and Serrate (Jagged in mammals). As a result of receptor activation, Notch receptor suffers a series of proteolytic cleavages that frees the intracellular domain of the Notch receptor (NICD) into the cytoplasm. The NICD then translocates to the nucleus, recruits the transcription factor Suppressor of Hairless [Su(H)] (CBF1/RJBk in mammals, LAG-1 in C. elegans) and mastermind co-factor protein, to form a complex that activates downstream target genes; the Enhancer of split (E(spl) genes in Drosophila and the HES or HESR in vertebrates as the main primary targets. This general picture of Notch signaling is a mere cartoon of the pathway further complicated with the isolation of many modulators of the Notch pathway(Artavanis-Tsakonas et al., 1999, Schweisguth, 2004, Louvi and Artavanis-Tsakonas, 2006).

Notch pathway regulates a long list of different biological processes: cell fate decisions, proliferation, apoptosis, cell differentiation, patterning and asymmetric divisions. Notch functions might differ by the modulation on the amount of the receptor or the ligand on the cell surface, by feedback loops that potentiate or shut off the signal, or by tissue specific co-factors (Schweisguth, 2004). The most obvious role of Notch pathway is its ability to influence its neighbouring cells, by one cell promoting one state and the adjacent cell adopting the antagonist state. Notch plays an indisputable role in neurogenesis, in which the Delta-positive

\section{TABLE 1}

\section{ORTHOLOGUES OF NOTCH PATHWAY COMPONENTS}

\begin{tabular}{|c|c|c|c|}
\hline fruit fly & mouse & chick & zebrafish \\
\hline Notch & $\begin{array}{l}\text { Notch1 }{ }^{+} \\
\text {Notch2 nd } \\
\text { Notch3 nd } \\
\text { Notch4 nd }\end{array}$ & $\begin{array}{l}\text { Notch1 }{ }^{+} \\
\text {Notch2 }\end{array}$ & $\begin{array}{l}\text { Notch1a, Notch1b + } \\
\text { Notch2 (Notch6) nd } \\
\text { Notch3 (Notch5) nd }\end{array}$ \\
\hline Delta & $\begin{array}{l}\text { Delta } 1^{+} \\
\text {Delta3 }{ }^{\text {nd }} \\
\text { Delta4 }{ }^{\text {nd }} \\
\text { Delta-like1 }\end{array}$ & $\begin{array}{l}\text { Delta1 + } \\
\text { Delta4 nd } \\
\text { nd }\end{array}$ & $\begin{array}{l}\text { DeltaA + } \\
\text { DeltaB + } \\
\text { Delta4 }{ }^{\text {nd }} \\
\text { DeltaC - } \\
\text { DeltaD + }\end{array}$ \\
\hline Serrate & $\begin{array}{l}\text { Jagged1 }{ }^{+} \\
\text {Jagged2 }{ }^{+}\end{array}$ & $\begin{array}{l}\text { Serrate1 }{ }^{+} \\
\text {Serrate2 }{ }^{+}\end{array}$ & $\begin{array}{l}\text { Jagged1a , Jagged 1b+ } \\
\text { Jagged } 2^{+}\end{array}$ \\
\hline Fringe & $\begin{array}{l}\text { Lunatic Fringe }^{+} \\
\text {Manic Fringe }{ }^{+} \\
\text {Radical Fringe }\end{array}$ & $\begin{array}{l}\text { Lunatic Fringe + } \\
\text { Manic Fringe - } \\
\text { Radical Fringe - }\end{array}$ & $\begin{array}{l}\text { Lunatic Fringe }^{+} \\
\text {Manic Fringe }{ }^{+} \\
\text {Radical Fringe }\end{array}$ \\
\hline Hairy & Hes $1^{+}$ & $\begin{array}{l}\text { Hairy2 }{ }^{+} \\
\text {Hairy } 1^{+}\end{array}$ & $\begin{array}{l}\text { her6 }(\text { Hes 14) nd } \\
\text { her9 nd }\end{array}$ \\
\hline$E(s p l)$ & $\begin{array}{l}\text { Hes6 }{ }^{+} \\
\text {Hes7 nd }\end{array}$ & $\begin{array}{l}\text { nd } \\
\text { nd } \\
\text { Hes5 } 5^{+}\end{array}$ & $\begin{array}{l}\text { her10 }{ }^{\text {nd }} \\
\text { her3 }{ }^{\text {nd }} \\
\text { her2 }{ }^{\text {nd }} \\
\text { her4 }{ }^{\text {nd }} \\
\text { her12 }{ }^{\text {nd }} \\
\text { her15 }^{\text {nd }} \\
\text { her6(Her13) }{ }^{\text {nd }} \\
\text { her8 }^{\text {nd }} \\
\text { her1 }^{\text {nd }} \\
\text { her7 }^{\text {nd }} \\
\text { her11 }^{\text {nd }}\end{array}$ \\
\hline Hey (YRPW) & $\begin{array}{l}\text { Hey1 nd } \\
\text { Hey2 nd } \\
\text { HeyL nd }\end{array}$ & $\begin{array}{l}\text { Hey1 nd } \\
\text { Hey2 nd } \\
\text { HeyL nd }\end{array}$ & $\begin{array}{l}\text { Hey1 }{ }^{\text {nd }} \\
\text { Hey2 } 2^{\text {nd }} \\
\text { HeyL (Hey3) }{ }^{\text {nd }}\end{array}$ \\
\hline
\end{tabular}

List of Notch pathway genes across species. Genes in brackets indicate alternative nomenclatures found in the literature. Data extracted mainly from ENSEMBL database, Sieger et al., 2004 and Landford and Kelley 2005. Super index lettering indicate presence (+), absence (-) or not determined (nd) expression in the developing inner ear. cell promotes neuronal fate and the Notch-activated cell represses neuronal fate (reviewed in Lewis, 1998). This phenomenon, in which Notch activity generates a negative feed-back loop by repressing its ligands, is referred as lateral inhibition. Generally, in those cases, the Notch activated cell remains as an undifferentiated progenitor cell and represses proneural gene activity, while the Delta-positive cell enters into differentiation. However, recent data also suggests that Notch pathway can promote differentiation, i.e. in glial differentiation. In Table 1 is listed the mouse, chick and zebrafish orthologues of Drosophila members of the Notch pathway.

Notch pathway also has the ability to segregate specific cell lineages from fields of developmentally equivalent cells; commonly, in this mechanism Notch operates by inducing its ligands, thus referred to as lateral induction. During neural vertebrate development, it has been reported to be essential for the segmentation of the hindbrain and the formation of the zona limitans intrathalamica (Lewis, 1998, Pasini and Wilkinson, 2002, Kiecker and Lumsden, 2005). Although the exact mechanism by which adjacent regional domains acquire distinct properties in vertebrates is less clear, the underlying model extracted from Drosophila predicts that Notch pathway is differentially activated by the different expression of Delta and Serrate ligands and the modulator Fringe in adjacent territories. Drosophila Fringe (Fng) and the vertebrate homologues Lunatic fng, Manic fngand Radical fng are glycosyl-transferases that glycosylate Notch EGF repeats, resulting in a bias of Notch receptor activation by Delta versus Serrate ligand (Rampal et al., 2005).

\section{Expression patterns and roles of Notch in the inner ear}

Mostly, Notch role in inner ear development has focused on sensory development due to the stunning phenotype on hair-cell production when Notch signaling is disrupted. A picture of the role of Notch pathway in inner ear development is emerging with the aid of a long list of mouse mutants and reported lines, complemented by genetic analysis in zebrafish (Lewis, 1998, Eddison et al., 2000, Landford and Kelley, 2005). Here we will briefly summarize the expression patterns of Notch elements and roles during sensory development to focus then on the earliest role of Notch on the regulation of the proneural domain based on our studies in chick.

\section{Notch function in sensory epithelia}

It has been reported that in mice, by E12, Notch1, Jag1 and LFngexpression start to be concentrated in the entire epithelium of the six sensory epithelia (Morrison et al., 1999). Simultaneously, $D / / 1$ ( $D / 1$ in non mammalian vertebrates) is expressed in scattered cells, presumably the nascent hair-cells of the vestibular epithelia (differentiates before the auditory epithelium). Later on, in E14-E15, D//1 and Jagged2 (Jag2) appear to be expressed also in the cochlea epithelium, again restricted to the cells that will become hair-cells (Morsli et al., 1998, Morrison et al., 1999), starting in the basal end of the cochlea to progressively extend to the apex. Hes 1 and Hes5transcripts have been detected only by RT-PCR at these stages (Shailam et al., 1999, Lanford et al., 2000). AtE15, Hes5expression is detected by in situhybridization at the base of the cochlea and by E17, when most cells have stopped dividing, LFng, Jagged1 (Jag1) and Hes5 expression 
restrict to supporting cells in the cochlea, while Jag2 and D//1 expressions are restricted to hair-cells (see revision in Landford and Kelley, 2005). Similar expression patterns are found in other species such as chick and zebrafish, where it has mostly been studied (Adam et al., 1998, Haddon et al., 1998, Eddison et al., 2000).

Defective Notch signaling in zebrafish or mammals (mutants for Jag2, Hes5, DI/1, mind bomb) results in overproduction of haircells at the expense of supporting cells, indicating that Notch signaling regulates sensory cell fate specification by a mechanism of lateral inhibition (Haddon etal., 1998, Lanford etal., 1999, Zine et al., 2000, Kiernan et al., 2001). Thus, Jag2/Dll1 ligands lead to the activation of Notch pathway and Hes5in adjacent cells that blocks hair-cell determination. Similar phenotypes of extra hair-cells are present in Foxg1 null mice, suggesting possible interactions of Hes proteins with forkhead box G1 proteins balancing cell proliferation and cell fate determination in the inner ear (Pauley et al., 2006, Fritzsch et al., 2006a). On the other hand, Jag1 is broadly expressed in the entire prosensory patches and different Jag1mice mutants result in total or partial loss of sensory epithelium, indicating that Jag 1 is required for the specification of the prosensory patch (Tsai et al., 2001, Daudet and Lewis, 2005, Brooker et al., 2006, Kiernan et al., 2006). Moreover, Jag1 is also required for maintenance of cells into a sensory progenitor state (Kiernan et al., 2006). The prevailing view is that in addition to regulate hair-cell specification, Notch-Jag1 signaling initially specifies sensory versus nonsensory epithelium within the ear, placing the limits by a lateral inductive mechanism (Adam et al., 1998, Lewis, 1998, Eddison et al., 2000, Landford and Kelley, 2005).
One of the possible models suggests that Notch activity in the nonsensory epithelium driven by Jag 1 binding from the sensory epithelium represses sensory fate. Consistent with this hypothesis, Notch inactivation in zebrafish leads to an expansion of sensory fate and similar results where obtained in the cochlea of conditional mutants for Notch1 (Kiernan etal., 2001). However, as mentioned, conditional Jag1 deletion in the otocyst does not phenocopy the results of Notch1 inactivation but rather suggests that Notch pathway is activated in the sensory epithelium. Moreover, in chick overexpression of NICD causes the induction of extra sensory patches (Daudet and Lewis, 2005). Altogether, it has been proposed that Notch activity is required for sensory development to first, make cells competent to form a prosensory patch conferring them a prosensory character and, subsequently, inhibit hair-cell differentiation and establish a mosaic cellular pattern (Daudet and Lewis, 2005).

\section{Notch function in the proneural domain}

Before the appearance of the sensory patches, when an early proneural domain establishes, most members of Notch pathway are already expressed in the otic placode/cup. In chick, Notch 1 is expressed in the entire otic epithelium from 11 somites to late otocyst stage (Groves and Bronner-Fraser, 2000). LFng is expressed throughout the proneural domain, while $D / 1$ is detected in a salt and pepper pattern (Adam et al., 1998, Cole et al., 2000, Alsina et al., 2004). In the same domain, Hes5 is expressed in cells adjacent to D/1-positive cells as a consequence of the N-DI lateral inhibition process (Fig. 3) (Abelló et al., 2007). Hes6in the neural tube is expressed both in precursor and differentiated
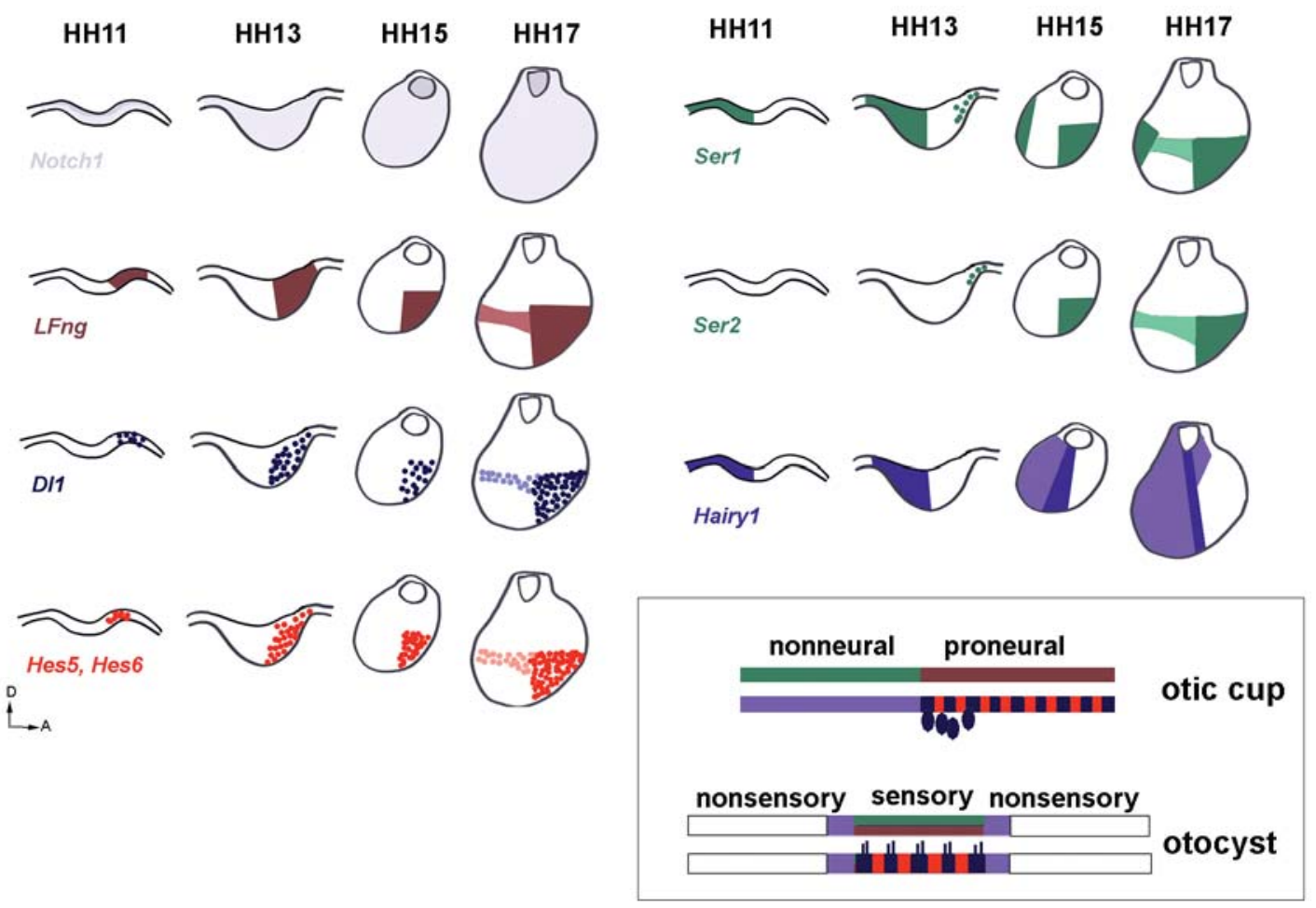

Fig. 3. Schematic lateral views of developing chick inner ears from otic placode (HH11) to otic vesicle stage (HH17) with expression profiles of members of the Notch pathway. Dotted pattern represents mRNA expression in scattered or clusters of cells. Dorsal up and anterior to the right. 
neurons (Fior and Henrique, 2005) and in the chick inner ear shows a mosaic pattern in the proneural domain (G.A and B.A unpublished observations). In the sensory patches, Hes6expression is very similar to Atoh1 (Qian et al., 2006). Therefore, LFng, Hes5, D/1 and Hes6 domains of expression extend from otic cup to late otocyst, as a common toolkit mechanism for the selection of first, neuronal and, second, sensory cells. As expected from the lateral inhibition model, disruption of Notch signaling in the mind bombmutant zebrafish or in chick by inhibiting Notch intracellular cleavage leads to the production of excess neuronal precursors in the inner ear concomitant to the suppression of Hes5activation (Haddon et al., 1998, Abelló et al., 2007). Altogether, Notch signaling is required in otic neurogenesis to regulate the number of neural committed cells that enter into neuronal differentiation.

Interestingly, Ser1 (or Jag 1) is also expressed already at early otic cup stage, well before the appearance of prosensory patches. In this case, Ser1 appears broadly in a domain complementary to the proneural domain. Later on, Ser1 also is distinguished in the proneural domain together with Ser2 in a scattered manner. About the same initial stage, Hes 1 is also restricted in the nonneural region, initially with a broad posterior expression to progressively increase the levels in a narrow lateral band adjacent to the proneural domain. In summary, the nonneural region is initially characterized by a domain with Notch, Jag1 and Hes 1 and devoid of $L F n g$ and $D / 1$ (Fig. 3). The early complementary expressions of Ser $1 /$ Hes 1 and $D / 1 / L F n g / H e s 5$ may reflect a role of Notch in distinguishing a proneural domain from a nonneural domain. During the stabilization of the proneural domain, one can propose that Notch activity through Ser1 binding in the nonneural domain, may result in Hes 1 activation to inhibit there proneural activity. However, blockade of Notch activity in chick before the appearance of Hes 1 expression does not expand the proneural domain, albeit Hes 1 is downregulated (Abelló et al., 2007). This indicates that either other factors, such as $T b \times 1$, may repress proneural fate in the nonneural region or that Notch activity is not required to suppress neural fate. This is in accordance with the results in chick previously mentioned in which Notch activity promotes sensory fate rather that inhibiting it. In mice, NICD is only detected in the proneural domain at otic vesicle stage (Xu et al., 2007). Detail mapping of NICD and Hes 1 expressions from otic placode/cup stage to otic vesicle stage is required in mammals and chick. Early blockade of Notch at 6-9 somites, does not hamper the development of proneural domain but affects the restricted expression of nonneural genes such as $L m x 1$ (Abelló et al., 2007). In agreement with this idea, in embryonic stem cells Notch activity promotes neural competence, synchronizes cells with Sox1 and promotes neural character by inhibiting nonneural fates (Lowell et al., 2006).

\section{Summary}

The early development of the inner ear is tightly linked to the emergence of a proneural domain with neurogenic capacity expressing the proneural gene Neurogenin1. Preceding the establishment of the proneural domain, SoxB1 genes distinguish a broad otic and epibranchial field foreshadowing the neural competent domain. Several models have been proposed for how neural competence is acquired. Yet, lacking many functional studies we envisage a multi-inductive process in which first, a placodal induction is followed by a neural induction. Restricted anterior proneural function would result of a combination of i) inhibitory factors acting in the posterior region plus ii) anterior enhancement of proneural activity by local otic FGFs. Notch activity in the proneural field is not required for the establishment of the proneural field but to maintain a pool of progenitors with proneural character.

\section{Acknowledgments}

We are grateful to Domingos Henrique for helpful discussions. We are indebted to the colleagues who participated in work reviewed in this paper: Joana Neves, Cristina Pujades and Fernando Giraldez. The Ministerio de Ciencia y Tecnología supported us.

\section{References}

ABELLO, G., KHATRI, S., GIRALDEZ, F. and ALSINA, B. (2007). Early regionalization of the otic placode and its regulation by the Notch pathway. Mech. Dev. 124: 631-645. DOI10.1016/j.mod.2007.04.002.

ABU-ELMAGD, M., ISHII, Y., CHEUNG, M., REX, M., LE ROUEDEC, D. and SCOTTING, P.J. (2001). cSox3 expression and neurogenesis in the epibranchial placodes. Dev. Biol., 237:258-269.

ADAM, J., MYAT, A., LE, R., I, EDDISON, M., HENRIQUE, D., ISH-HOROWICZ, D. and LEWIS, J. (1998). Cell fate choices and the expression of Notch, Delta and Serrate homologues in the chick inner ear: parallels with Drosophila senseorgan development. Development, 125:4645-4654.

ADAMSKA, M., HERBRAND, H., ADAMSKI, M., KRUGER, M., BRAUN, T. and BOBER, E. (2001). FGFs control the patterning of the inner ear but are not able to induce the full ear program. Mech. Dev. 109:303-313.

AHRENS, K. and SCHLOSSER, G. (2005). Tissues and signals involved in the induction of placodal Six1 expression in Xenopus laevis. Dev. Biol. 288: 40-59.

ALSINA, B., ABELLO, G., ULLOA, E., HENRIQUE, D., PUJADES, C. and GIRALDEZ, $F$. (2004). FGF signaling is required for determination of otic neuroblasts in the chick embryo. Dev. Biol., 267:119-134.

ALSINA, B., GIRALDEZ, F. and VARELA-NIETO, I. (2003). Growth factors and early development of otic neurons: interactions between intrinsic and extrinsic signals. Curr. Top. Dev. Biol., 57:177-206.

ANDERMANN, P., UNGOS, J. and RAIBLE, D. W. (2002). Neurogenin1 defines zebrafish cranial sensory ganglia precursors. Dev. Biol., 251:45-58.

ARTAVANIS-TSAKONAS, S., RAND, M. D. and LAKE, R. J. (1999). Notch signaling: cell fate control and signal integration in development. Science, 284:770776.

BAE, Y. K., SHIMIZU, T. and HIBI, M. (2005). Patterning of proneuronal and interproneuronal domains by hairy- and enhancer of split-related genes in zebrafish neuroectoderm. Development, 132:1375-1385.

BAKER, C. V. and BRONNER-FRASER, M. (2000). Establishing neuronal identity in vertebrate neurogenic placodes. Development, 127:3045-3056.

BAKER, C. V. and BRONNER-FRASER, M. (2001). Vertebrate cranial placodes I. Embryonic induction. Dev. Biol., 232:1-61.

BEGBIE, J., BALLIVET, M. and GRAHAM, A. (2002). Early steps in the production of sensory neurons by the neurogenic placodes. Mol. Cell Neurosci., 21:502511.

BERTRAND, N., CASTRO, D. S. and GUILLEMOT, F. (2002). Proneural genes and the specification of neural cell types. Nat. Rev Neurosci., 3:517-530.

BHATTACHARYYA, S., BAILEY, A. P., BRONNER-FRASER, M. and STREIT, A. (2004). Segregation of lens and olfactory precursors from a common territory: cell sorting and reciprocity of Dlx5 and Pax6 expression. Dev. Biol., 271:403414.

BHATTACHARYYA, S. and BRONNER-FRASER, M. (2004). Hierarchy of regulatory events in sensory placode development. Curr. Opin. Genet. Dev., 14:520526.

BOEKHOFF-FALK, G. (2005). Hearing in Drosophila: development of Johnston's organ and emerging parallels to vertebrate ear development. Dev. Dyn., 232:550-558. 
BROOKER, R., HOZUMI, K. and LEWIS, J. (2006). Notch ligands with contrasting functions: Jagged1 and Delta1 in the mouse inner ear. Development, 133:12771286.

CALDWELL, J. C. and EBERL, D. F. (2002). Towards a molecular understanding of Drosophila hearing. J. Neurobiol., 53:172-189.

CAMARERO, G., LEON, Y., GOROSPE, I., DE PABLO, F., ALSINA, B., GIRALDEZ, F. and VARELA-NIETO, I. (2003). Insulin-like growth factor 1 is required for survival of transit-amplifying neuroblasts and differentiation of otic neurons. Dev. Biol., 262:242-253.

CAU, E., GRADWOHL, G., CASAROSA, S., KAGEYAMA, R. and GUILLEMOT, F. (2000). Hes genes regulate sequential stages of neurogenesis in the olfactory epithelium. Development, 127:2323-2332.

CHAPMAN, D. L., GARVEY, N., HANCOCK, S., ALEXIOU, M., AGULNIK, S. I., GIBSON-BROWN, J. J., CEBRA-THOMAS, J., BOLLAG, R. J., SILVER, L. M. and PAPAIOANNOU, V. E. (1996). Expression of the T-box family genes, Tbx1Tbx5, during early mouse development. Dev. Dyn., 206:379-390.

CHEN, P., JOHNSON, J. E., ZOGHBI, H. Y. and SEGIL, N. (2002). The role of Math1 in inner ear development: Uncoupling the establishment of the sensory primordium from hair cell fate determination. Development. 129:2495-2505.

CHOO, D., WARD, J., REECE, A., DOU, H., LIN, Z. and GREINWALD, J. (2006). Molecular mechanisms underlying inner ear patterning defects in kreisler mutants. Dev. Biol. 289:308-317.

COLE, L. K., LE, R., I, NUNES, F., LAUFER, E., LEWIS, J. and WU, D. K. (2000). Sensory organ generation in the chicken inner ear: contributions of bone morphogenetic protein 4, serrate1 and lunatic fringe. J. Comp Neurol., 424:509520.

CREMAZY, F., BERTA, P. and GIRARD, F. (2000). Sox neuro, a new Drosophila Sox gene expressed in the developing central nervous system. Mech. Dev. 93:215-219.

D'AMICO-MARTEL, A. (1982). Temporal patterns of neurogenesis in avian cranial sensory and autonomic ganglia. Am. J Anat., 163:351-372.

DAUDET, N. and LEWIS, J. (2005). Two contrasting roles for Notch activity in chick inner ear development: specification of prosensory patches and lateral inhibition of hair-cell differentiation. Development, 132:541-551.

DONNER, A. L., EPISKOPOU, V. and MAAS, R. L. (2007). Sox2 and Pou2f1 interact to control lens and olfactory placode development. Dev. Biol. 303:784799.

EDDISON, M., LE, R., I and LEWIS, J. (2000). Notch signaling in the development of the inner ear: lessons from Drosophila. Proc. Natl. Acad. Sci. USA, 97:1169211699.

FETTIPLACE, R. and HACKNEY, C. M. (2006). The sensory and motor roles of auditory hair cells. Nat. Rev. Neurosci, 7:19-29.

FIOR, R. and HENRIQUE, D. (2005). A novel hes5/hes6 circuitry of negative regulation controls Notch activity during neurogenesis. Dev. Biol., 281:318-333.

FRITZSCH, B. and BEISEL, K. W. (2001). Evolution and development of the vertebrate ear. Brain Res. Bull., 55:711-721.

FRITZSCH, B., BEISEL, K. W. and HANSEN, L. A. (2006a). The molecular basis of neurosensory cell formation in ear development: a blueprint for hair cell and sensory neuron regeneration? Bioessays, 28:1181-1193.

FRITZSCH, B., BEISEL, K. W., JONES, K., FARINAS, I., MAKLAD, A., LEE, J. and REICHARDT, L. F. (2002). Development and evolution of inner ear sensory epithelia and their innervation. J. Neurobiol., 53:143-156.

FRITZSCH, B., PAULEY, S. and BEISEL, K. W. (2006b). Cells, molecules and morphogenesis: the making of the vertebrate ear. Brain Res., 1091:151-171.

GELING, A., ITOH, M., TALLAFUSS, A., CHAPOUTON, P., TANNHAUSER, B., KUWADA, J. Y., CHITNIS, A. B. and BALLY-CUIF, L. (2003). bHLH transcription factor Her5 links patterning to regional inhibition of neurogenesis at the midbrain-hindbrain boundary. Development, 130:1591-1604.

GHYSEN, A. and DAMBLY-CHAUDIERE, C. (1989). Genesis of the Drosophila peripheral nervous system. Trends Genet., 5:251-255.

GHYSEN, A. and RICHELLE, J. (1979). Determination of sensory bristles and pattern formation in Drosophila. II. The achaete-scute locus. Dev. Biol., 70:438452.

GROVES, A. K. (2005). The Induction of the Otic Placode. In Development of the
Inner Ear. Handbook of Auditory Reserarch. Kelley M., Wu D.K, Popper A.N., Fay R.R., ed. Springer, 26, 2:10-42.

GROVES, A. K. and BRONNER-FRASER, M. (2000). Competence, specification and commitment in otic placode induction. Development, 127:3489-3499.

HADDON, C., JIANG, Y. J., SMITHERS, L. and LEWIS, J. (1998). Delta-Notch signalling and the patterning of sensory cell differentiation in the zebrafish ear: evidence from the mind bomb mutant. Development, 125:4637-4644.

HANS, S., CHRISTISON, J., LIU, D. and WESTERFIELD, M. (2007). Fgf-dependent otic induction requires competence provided by Foxi1 and DIx3b. BMC. Dev. Biol. 7:5.

HEMOND, S. G. and MOREST, D. K. (1991). Ganglion formation from the otic placode and the otic crest in the chick embryo: mitosis, migration and the basal lamina. Anat. Embryol. (Berl), 184:1-13.

HENRIQUE, D., TYLER, D., KINTNER, C., HEATH, J. K., LEWIS, J. H., ISHHOROWICZ, D. and STOREY, K. G. (1997). cash4, a novel achaete-scute homolog induced by Hensen's node during generation of the posterior nervous system. Genes Dev., 11:603-615.

JACOBSON, A. G. (1963). THE DETERMINATION AND POSITIONING OF THE NOSE, LENS AND EAR. I. INTERACTIONS WITHIN THE ECTODERM and BETWEEN THE ECTODERM AND UNDERLYING TISSUES. J. Exp. Zool, 154:273-283.

KAMACHI, Y., UCHIKAWA, M., COLLIGNON, J., LOVELL-BADGE, R. and $\mathrm{KONDOH}, \mathrm{H}$. (1998). Involvement of Sox1, 2 and 3 in the early and subsequent molecular events of lens induction. Development, 125:2521-2532.

KIECKER, C. and LUMSDEN, A. (2005). Compartments and their boundaries in vertebrate brain development. Nat. Rev. Neurosci, 6:553-564.

KIERNAN, A. E., AHITUV, N., FUCHS, H., BALLING, R., AVRAHAM, K. B., STEEL, K. P. and HRABE, d. A. (2001). The Notch ligand Jagged1 is required for inner ear sensory development. Proc. Natl. Acad. Sci. USA, 98:3873-3878.

KIERNAN, A. E., PELLING, A. L., LEUNG, K. K., TANG, A. S., BELL, D. M., TEASE, C., LOVELL-BADGE, R., STEEL, K. P. and CHEAH, K. S. (2005). Sox2 is required for sensory organ development in the mammalian inner ear. Nature, 434:1031-1035.

KIERNAN, A. E., XU, J. and GRIDLEY, T. (2006). The Notch ligand JAG1 is required for sensory progenitor development in the mammalian inner ear. PLOS. Genet., 2:e4.

KIM, W. Y., FRITZSCH, B., SERLS, A., BAKEL, L. A., HUANG, E. J., REICHARDT, L. F., BARTH, D. S. and LEE, J. E. (2001). NeuroD-null mice are deaf due to a severe loss of the inner ear sensory neurons during development. Development, 128:417-426.

KOSTER, R. W., KUHNLEIN, R. P. and WITTBRODT, J. (2000). Ectopic Sox3 activity elicits sensory placode formation. Mech. Dev. 95:175-187.

KWAK, S. J., PHILLIPS, B. T., HECK, R. and RILEY, B. B. (2002). An expanded domain of fgf3 expression in the hindbrain of zebrafish valentino mutants results in mis-patterning of the otic vesicle. Development. 129:5279-5287.

LANDFORD, P. J. and KELLEY, M. W. (2005). Notch Signaling and Cell Fate Specification. In Development of the Inner Ear. Handbook of Auditory Reserarch. Kelley M., Wu D.K, Popper A.N., Fay R.R., ed. Springer, 26, 5:122-157.

LANFORD, P. J., LAN, Y., JIANG, R., LINDSELL, C., WEINMASTER, G., GRIDLEY, T. and KELLEY, M. W. (1999). Notch signalling pathway mediates hair cell development in mammalian cochlea. Nat. Genet., 21:289-292.

LANFORD, P. J., SHAILAM, R., NORTON, C. R., GRIDLEY, T. and KELLEY, M. W. (2000). Expression of Math1 and HES5 in the cochleae of wildtype and Jag2 mutant mice. J. Assoc. Res. Otolaryngol. 1:161-171.

LECAUDEY, V., ULLOA, E., ANSELME, I., STEDMAN, A., SCHNEIDERMAUNOURY, S. and PUJADES, C. (2007). Role of the hindbrain in patterning the otic vesicle: a study of the zebrafish vhnf1 mutant. Dev. Biol. 303:134-143.

LEGER, S. and BRAND, M. (2002). Fgf8 and Fgf3 are required for zebrafish ear placode induction, maintenance and inner ear patterning. Mech. Dev., 119:91108.

LEWIS, J. (1998). Notch signalling and the control of cell fate choices in vertebrates. Semin. Cell Dev. Biol., 9:583-589.

LITSIOU, A., HANSON, S. and STREIT, A. (2005). A balance of FGF, BMP and WNT signalling positions the future placode territory in the head. Development 
132:4051-4062.

LOUVI, A. and ARTAVANIS-TSAKONAS, S. (2006). Notch signalling in vertebrate neural development. Nat. Rev. Neurosci., 7:93-102.

LOWELL, S., BENCHOUA, A., HEAVEY, B. and SMITH, A. G. (2006). Notch promotes neural lineage entry by pluripotent embryonic stem cells. PLOS. Biol. 4:e121.

MA, Q., ANDERSON, D. J. and FRITZSCH, B. (2000). Neurogenin 1 null mutant ears develop fewer, morphologically normal hair cells in smaller sensory epithelia devoid of innervation. J Assoc. Res. Otolaryngol., 1:129-143.

MANSOUR, S. L., GODDARD, J. M. and CAPECCHI, M. R. (1993). Mice homozygous for a targeted disruption of the proto-oncogene int-2 have developmental defects in the tail and inner ear. Development., 117:13-28.

MARTIN, K. and GROVES, A. K. (2006). Competence of cranial ectoderm to respond to Fgf signaling suggests a two-step model of otic placode induction. Development. 133: 877-887.

MATEI, V., PAULEY, S., KAING, S., ROWITCH, D., BEISEL, K. W., MORRIS, K., FENG, F., JONES, K., LEE, J. and FRITZSCH, B. (2005). Smaller inner ear sensory epithelia in Neurog 1 null mice are related to earlier hair cell cycle exit. Dev. Dyn., 234:633-650.

MCKAY, I. J., LEWIS, J. and LUMSDEN, A. (1996). The role of FGF-3 in early inner ear development: an analysis in normal and kreisler mutant mice. Dev. Biol.,174: 370-378.

MILLIMAKI, B. B., SWEET, E. M., DHASON, M. S. and RILEY, B. B. (2007). Zebrafish atoh1 genes: classic proneural activity in the inner ear and regulation by Fgf and Notch. Development. 2007. Jan.,134. (2):295. -305. Epub. 2006. Dec. 13., 134:295-305.

MORRISON, A., HODGETTS, C., GOSSLER, A., HRABE, d. A. and LEWIS, J. (1999). Expression of Delta1 and Serrate1 (Jagged1) in the mouse inner ear. Mech. Dev., 84:169-172.

MORSLI, H., CHOO, D., RYAN, A., JOHNSON, R. and WU, D. K. (1998). Development of the mouse inner ear and origin of its sensory organs. J. Neurosci., 18:3327-3335.

NECHIPORUK, A., LINBO, T., POSS, K. D. and RAIBLE, D. W. (2007). Specification of epibranchial placodes in zebrafish. Development, 134:611-623.

NEVES, J., KAMAID A., ALSINA B. and GIRALDEZ F. (2007). Differential expression of Sox2 and Sox3 in neuronal and sensory progenitors of the developing inner ear. J. Comp. Neurol., 503: 487-500. DOI 10.1002/cne.21299.

NIKAIDO, M., DOI, K., SHIMIZU, T., HIBI, M., KIKUCHI, Y. and YAMASU, K. (2007). Initial specification of the epibranchial placode in zebrafish embryos depends on the fibroblast growth factor signal. Dev. Dyn. 236:564-571.

NODEN, D. M. and VAN DE WATER, T. R. (1986). The developing ear: Tissue origins and interactions. The Biology of Change in Otolaryngology,15-46.

ORENIC, T. V., HELD, L. I., Jr., PADDOCK, S. W. and CARROLL, S. B. (1993). The spatial organization of epidermal structures: hairy establishes the geometrical pattern of Drosophila leg bristles by delimiting the domains of achaete expression. Development.,118: 9-20.

PASINI, A. and WILKINSON, D. G. (2002). Stabilizing the regionalisation of the developing vertebrate central nervous system. Bioessays, 24:427-438.

PAULEY, S., LAI, E. and FRITZSCH, B. (2006). Foxg1 is required for morphogenesis and histogenesis of the mammalian inner ear. Dev. Dyn., 235:2470-2482.

PERA, E. M., IKEDA, A., EIVERS, E. and DE ROBERTIS, E. M. (2003). Integration of IGF, FGF and anti-BMP signals via Smad1 phosphorylation in neural induction. Genes Dev. 2003. 17:3023-3028.

PERRON, M., OPDECAMP, K., BUTLER, K., HARRIS, W. A. and BELLEFROID, E. J. (1999). X-ngnr-1 and Xath3 promote ectopic expression of sensory neuron markers in the neurula ectoderm and have distinct inducing properties in the retina. Proc. Natl. Acad. Sci. USA, 96:14996-15001.

PEVNY, L. and PLACZEK, M. (2005). SOX genes and neural progenitor identity. Curr. Opin. Neurobiol., 15:7-13.

PEVNY, L. H., SOCKANATHAN, S., PLACZEK, M. and LOVELL-BADGE, R. (1998). A role for SOX1 in neural determination. Development., 125:1967-1978.

PIRVOLA, U., YLIKOSKI, J., TROKOVIC, R., HEBERT, J. M., MCCONNELL, S. K. and PARTANEN, J. (2002). FGFR1 is required for the development of the auditory sensory epithelium. Neuron, 35:671-680.
PUJADES, C., KAMAID, A., ALSINA, B. and GIRALDEZ, F. (2006). BMP-signaling regulates the generation of hair-cells. Dev. Biol., 292:55-67.

QIAN, D., RADDE-GALLWITZ, K., KELLY, M., TYRBERG, B., KIM, J., GAO, W. Q. and CHEN, P. (2006). Basic helix-loop-helix gene Hes6 delineates the sensory hair cell lineage in the inner ear. Dev. Dyn. 235: 1689-1700.

RAFT, S., NOWOTSCHIN, S., LIAO, J. and MORROW, B. E. (2004). Suppression of neural fate and control of inner ear morphogenesis by Tbx1. Development, 131:1801-1812.

RAMPAL, R., LI, A. S., MOLONEY, D. J., GEORGIOU, S. A., LUTHER, K. B., NITALAZAR, A. and HALTIWANGER, R. S. (2005). Lunatic fringe, manic fringe and radical fringe recognize similar specificity determinants in O-fucosylated epidermal growth factor-like repeats. J. Biol. Chem. 280: 42454-42463.

REX, M., ORME, A., UWANOGHO, D., TOINTON, K., WIGMORE, P. M., SHARPE, P. T. and SCOTTING, P. J. (1997). Dynamic expression of chicken Sox2 and Sox3 genes in ectoderm induced to form neural tissue. Dev. Dyn.,209: 323-332.

RILEY, B. B. and PHILLIPS, B. T. (2003). Ringing in the new ear: resolution of cell interactions in otic development. Dev. Biol., 261:289-312.

SATOH, T. and FEKETE, D. M. (2005). Clonal analysis of the relationships between mechanosensory cells and the neurons that innervate them in the chicken ear. Development, 132:1687-1697.

SCHLOSSER, G. (2006). Induction and specification of cranial placodes. Dev. Biol., 294:303-351.

SCHLOSSER, G. and AHRENS, K. (2004). Molecular anatomy of placode development in Xenopus laevis. Dev. Biol. 271:439-466.

SCHLOSSER, G. and NORTHCUTT, R. G. (2000). Development of neurogenic placodes in Xenopus laevis. J. Comp Neurol., 418:121-146.

SCHWEISGUTH, F. (2004). Notch signaling activity. Curr. Biol., 14:R129-R138.

SHAILAM, R., LANFORD, P. J., DOLINSKY, C. M., NORTON, C. R., GRIDLEY, T. and KELLEY, M. W. (1999). Expression of proneural and neurogenic genes in the embryonic mammalian vestibular system. J. Neurocytol., 28:809-819.

SHENG, G., DOS, R. M. and STERN, C. D. (2003). Churchill, a zinc finger transcriptional activator, regulates the transition between gastrulation and neurulation. Cell. 115:603-613.

SIMPSON, P. (1990). Lateral inhibition and the development of the sensory bristles of the adult peripheral nervous system of Drosophila. Development, 109:509519.

STERN, C. D. 2005. Neural induction: old problem, new findings, yet more questions. Development. 132:2007-2021.

STREIT, A. (2004). Early development of the cranial sensory nervous system: from a common field to individual placodes. Dev. Biol., 276:1-15.

STREIT, A., BERLINER, A. J., PAPANAYOTOU, C., SIRULNIK, A. and STERN, C. D. (2000). Initiation of neural induction by FGF signalling before gastrulation Nature, 406:74-78.

SUN, S. K., DEE, C. T., TRIPATHI, V. B., RENGIFO, A., HIRST, C. S. and SCOTTING, P. J. (2007). Epibranchial and otic placodes are induced by a common Fgf signal, but their subsequent development is independent. Dev. Biol. 303:675-686.

TAKEMOTO, T., UCHIKAWA, M., KAMACHI, Y. and KONDOH, H. (2006). Convergence of Wnt and FGF signals in the genesis of posterior neural plate through activation of the Sox2 enhancer N-1. Development. 133:297-306.

TORRES, M. and GIRALDEZ, F. (1998). The development of the vertebrate inner ear. Mech. Dev., 71:5-21.

TREISMAN, J. E. (2004). Coming to our senses. Bioessays, 26:825-828.

TSAI, H., HARDISTY, R. E., RHODES, C., KIERNAN, A. E., ROBY, P., TYMOWSKALALANNE, Z., MBURU, P., RASTAN, S., HUNTER, A. J., BROWN, S. D. and STEEL, K. P. 2001. The mouse slalom mutant demonstrates a role for Jagged1 in neuroepithelial patterning in the organ of Corti. Hum. Mol. Genet. 10:507-512.

VITELLI, F., VIOLA, A., MORISHIMA, M., PRAMPARO, T., BALDINI, A. and LINDSAY, E. (2003). TBX1 is required for inner ear morphogenesis. Hum. Mol. Genet. 12:2041-2048.

WRIGHT, T. J. and MANSOUR, S. L. (2003). FGF signaling in ear development and innervation. Curr. Top. Dev. Biol. 57:225-259.

XU, H., VIOLA, A., ZHANG, Z., GERKEN, C. P., LINDSAY-ILLINGWORTH, E. A. 
and BALDINI, A. (2007). Tbx1 regulates population, proliferation and cell fate determination of otic epithelial cells. Dev. Biol. 302:670-682.

YAGER, D. D. (1999). Structure, development and evolution of insect auditory systems. Microsc. Res. Tech., 47:380-400.

ZINE, A., VAN DE WATER, T. R. and DE RIBAUPIERRE, F. (2000). Notch signaling regulates the pattern of auditory hair cell differentiation in mammals. Develop- ment, 127:3373-3383.

ZUR LAGE, P. I., POWELL, L. M., PRENTICE, D. R., MCLAUGHLIN, P. and JARMAN, A. P. (2004). EGF receptor signaling triggers recruitment of Drosophila sense organ precursors by stimulating proneural gene autoregulation. Dev. Cell, 7:687-696.

\section{Related, previously published Int. J. Dev. Biol. articles}

See our Special Issue Ear Development edited by Fernando Giraldez and Bernd Fritzsch at: http://www.ijdb.ehu.es/web/contents.php?vol=51\&issue=6-7

A change in response to Bmp signalling precedes ectodermal fate choice

Chris T. Dee, Abigail Gibson, Andrea Rengifo, Shun-Kuo Sun, Roger K. Patient and Paul J. Scotting Int. J. Dev. Biol. (2007) 51: 79-84

Analysis of Netrin 1 receptors during inner ear development

Tanja Matilainen, Maarja Haugas, Jordan A. Kreidberg and Marjo Salminen

Int. J. Dev. Biol. (2007) 51: 409-414

Cell proliferation during the early compartmentalization of the Xenopus laevis inner ear Quincy A. Quick and Elba E. Serrano Int. J. Dev. Biol. (2007) 51: 201-210

Retinoic acid is required for specification of the ventral eye field and for Rathke's pouch in the avian embryo Malcolm Maden, Aida Blentic, Susan Reijntjes, Sophie Seguin, Emily Gale and Anthony Graham Int. J. Dev. Biol. (2007) 51: 191-200

Expression of Bmp ligands and receptors in the developing Xenopus retina Jennifer C. Hocking and Sarah McFarlane

Int. J. Dev. Biol. (2007) 51: 161-165

Interplay between FGF10 and Notch signalling is required for the self-renewal of pancreatic progenitors Francisco Miralles, Luciane Lamotte, Dominique Couton and Rajiv L. Joshi Int. J. Dev. Biol. (2006) 50: 17-26

Notch in vertebrates - molecular aspects of the signal

Ken-Ichi Katsube and Kei Sakamoto

Int. J. Dev. Biol. (2005) 49: 369-374

Activin-like signaling activates Notch signaling during mesodermal induction Takanori Abe, Miho Furue, Yasufumi Myoishi, Tetsuji Okamoto, Akiko Kondow and Makoto Asashima Int. J. Dev. Biol. (2004) 48: 327-332

Evolution of cis-regulation of the proneural genes. Jean-Michel Gibert and Pat Simpson Int. J. Dev. Biol. (2003) 47: 643-651

The bHLH genes in neural development.

$\mathrm{C}$ Dambly-Chaudière and $\mathrm{M}$ Vervoort Int. J. Dev. Biol. (1998) 42: 269-273 